\title{
Prospect of Natural Gas Utilization in China
}

\author{
Wei Huang ${ }^{1}$, Hongjun You ${ }^{2}$ \\ ${ }^{1}$ School of Environment and Biological Engineering, Liao Ning Shihua University, Fushun, China \\ ${ }^{2}$ Southern Alberta Institute of Technology Polytechnic, Calgary, Canada \\ E-mail: youhongjun@hotmail.com \\ Received February 15, 2011; revised March 21, 2011; accepted March 28, 2011
}

\begin{abstract}
This paper introduces the source and utility circumstance of natural gas in China. The utility circumstance of natural gas is discussed in detail, such as, natural gas as feedstock is produced to acetylene; natural gas is used to cut metal; natural gas is applied to generate ethylene; natural gas instead of heavy oil is fired to produce chromium trioxide. In so doing, the energy demand of China will be better met with least damage to the environment. According to the full utility of natural gas sources, their good economic and social benefits are obtained.
\end{abstract}

Keywords: Natural Gas, Utilization, China, Environment, Energy Demand

\section{Introduction}

With the decrease of petroleum energy, it is very important to utilize Chinese traditional energy such as coal and natural gas and improve natural gas as high value production. It has a good economic benefit and society benefit [1]. Chinese economic and social development is limited due to the shortage of natural resource. The output of Chinese petroleum basically keeps at between 1.8 * $10^{8}$ t per year and $2.5 * 10^{8}$ t per year [2]. However, Chinese usable petroleum source are reserved at $32.7 *$ $10^{8} \mathrm{t}$ per year. Chinese petroleum exploration only has 16 years. And 52\% petroleum comes from overseas. So Chinese government uses the different policy to decrease the power loss and increase production efficiency and decrease tax for those companies that try to keep the nature source and develop the new source such as wind resource, water resource and natural gas source, and so on.

At present, utilization of natural gas in China is low efficiency and proceeds in a way that quickly degrades the environment and caused serious pollution. The local residents almost depend on natural gas for cooking and space heating. Most of natural gas is directly burnt as fuel for cooking. Due to using outdated stoves, the burning efficiency is very low, utilizing less than $30 \%$ of electricity energy.

In conclusion, the overuse of traditional energy (natural gas) as fuel in partial area damages the fragile environment. There exists an urgent need to utilize natural gas in a rational way, which can be done through using new method to improve production value. This will not only improve energy efficiency, but also reduce pollution and damage the ecological environment. In this paper, the five main methods are introduced. Natural gas as feedstock is produced to acetylene, ethylene and chromium trioxide, respectively; natural gas is used to cut metal and produced to chromium trioxide instead of heavy oil.

\section{Natural Gas Utilization in China}

\subsection{Natural Gas Produced to Acetylene}

Zhang Xiangfu [3] introduced that natural gas as feedstock is produced to acetylene with the plasma method. The three methods for acetylene production were compared from the view point of technology and economics. The plasma method for acetylene production has more advantages than the partial oxidation and calcium carbide method. It was effectively used to save energy and decrease production capital and protect environment.

Figure 1 shows the relationship between temperature and free energy of hydrocarbons. When temperature is between $900 \mathrm{~K}$ and $1200 \mathrm{~K}$, free energies of hydrocarbon compounds are more than 0 and increase with the increase of temperature. But free energy of acetylene has high value at low temperature and decreases with the increase of temperature. When temperature is more than $1800 \mathrm{~K}$, free energy of acetylene is less than that of others. This proves that acetylene is firstly obtained than others. 


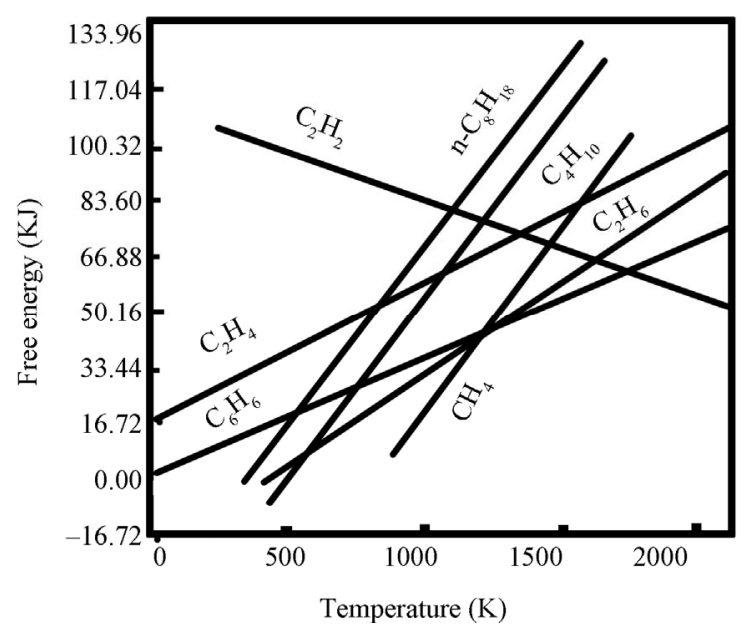

Figure 1. The relationship between temperature and free energy of hydrocarbons.

Natural gas between $3000 \mathrm{~K}$ and $5000 \mathrm{~K}$ is cracked by using the plasma method and separated to acetylene (main product) and hydrogen (by-product).

Advantages of the plasma method are as follows: 1) this processing is very simple and save investment and low capital. This method doesn't need oxygen and only requires natural gas, water and electricity. Table 1 shows the comparison of three methods between investment and energy consumption. The plasma method can get more benefits than other methods. 2) Feedstock of the plasma method mainly is natural gas or cheap petroleum gas which is easily obtained. 3 ) The crack gas is easily separated and purified.

\subsection{Natural Gas Used to Cut Metal}

Gong Yanwu [4] introduced that natural gas is used to cut metal. Natural gas as cutting gas gradually takes the place of propane and acetylene because high investment and high energy consumption. It limits to the development of propane and acetylene, such as, the feedstock of acetylene (calcium carbide) is one of high energy consumption product, $1 \mathrm{t}$ calcium carbide is got with the consumption of $3000 \mathrm{KWh}-5000 \mathrm{KWh}$ electricity and $0.5 \mathrm{t}$ standard coals. $3.5 \mathrm{t}$ calcium carbide residual and some harmful gas ( $\mathrm{CO}, \mathrm{H}_{2} \mathrm{~S}$ and $\mathrm{SO}_{2}$ ) are discharged; on the other hand propane's price quickly increases due to no more propane. So the appliance of natural gas instead of propane and acetylene has some advantages at the aspects of economic and environment and safety.

\subsubsection{Natural Gas' Characteristics}

Table 2 presents comparison about natural gas, propane and acetylene. Natural gas' explosion limit and burning point and burning speed are very low and slow, respect-
Table 1. The comparison of three methods between investment and energy consumption.

\begin{tabular}{lccc}
\hline \multicolumn{1}{c}{ Method } & plasma & partial oxidation & calcium carbide \\
\hline $\begin{array}{l}\text { Ratio of investment } \\
\text { and income }\end{array}$ & 1 & 3 & 2 \\
$\begin{array}{l}\text { Amount } \\
\text { Natural gas } \\
\left(\$ 0.98 / \mathrm{m}^{3}\right)\end{array}$ & $600 \mathrm{t} / \mathrm{y}$ & 2.87 million t/y & $\begin{array}{c}>0.67 \text { million } \\
\mathrm{t} / \mathrm{y}\end{array}$ \\
$\begin{array}{l}\text { Oxygen }\left(\$ 0.8 / \mathrm{m}^{3}\right) \\
\text { Hydrogen }\left(\$ 0.3 / \mathrm{m}^{3}\right)\end{array}$ & $\$ 2248$ & $\$ 6419$ & \\
$\begin{array}{l}\text { Coal }(\$ 500 / \mathrm{t}) \\
\begin{array}{l}\text { Electricity } \\
(\$ 0.464 / \mathrm{KWh})\end{array}\end{array}$ & $\$ 4872$ & & $\$ 2736$ \\
Feedstock & $\$ 8020$ & $\$ 9155$ & $\$ 825$ \\
& & & $\$ 5564$ \\
\hline
\end{tabular}

Table 2. Characteristics of three gases (natural gas, propane and acetylene).

\begin{tabular}{lccc}
\hline \multicolumn{1}{c}{ Gas } & Natural gas & Propane & Acetylene \\
\hline Volume (\%) & 0.75 & 2.0 & 1.2 \\
$\begin{array}{l}\text { Explosion limit (\%) } \\
\text { The lowest heat } \\
\text { value }\left(\mathrm{kcal} / \mathrm{m}^{3}\right)\end{array}$ & $5-15$ & $2.1-9.5$ & $2.5-80$ \\
$\begin{array}{l}\text { Theoretical oxygen } \\
\text { consumption } \\
\left(\mathrm{m}^{3} / \mathrm{m}^{3}\right)\end{array}$ & 8800 & 22256 & 12600 \\
$\begin{array}{l}\text { Burning speed } \\
(\mathrm{m} / \mathrm{s})\end{array}$ & 2 & 5 & 2.5 \\
Burning point $\left({ }^{\circ} \mathrm{C}\right)$ & $1850-2540$ & 2832 & $3100-3350$ \\
\hline
\end{tabular}

tively. So natural gas isn't easily explored and burnt than acetylene and has high safety performance. It has high efficiency and clean and doesn't produce calcium carbide residual. Its price is lower than that LPG, gasoline and diesel. Its utilization not only effectively decreases energy loss and reduces equipment corrosion and environmental pollution, but also improves the factory's competition, with great benefits reached by the industry.

\subsubsection{Service Method of Natural Gas}

Service methods of natural gas include piping natural gas (PNG) and compressing natural gas (CNG) and liquefying natural gas (LNG). Table 3 indicates characteristics

Table 3. Comparison of three methods of natural gas provided.

\begin{tabular}{cccc}
\hline $\begin{array}{c}\text { Providing me- } \\
\text { thod }\end{array}$ & PNG & CNG & LNG \\
\hline $\begin{array}{c}\text { Providing con- } \\
\text { dition }\end{array}$ & $\begin{array}{c}\text { Piping arrives } \\
\text { at place }\end{array}$ & $\begin{array}{c}\text { No piping, CNG } \\
\text { exists }\end{array}$ & Any area \\
$\begin{array}{c}\text { Storage } \\
\text { condition }\end{array}$ & No & $25 \mathrm{Mpa}$ & $-162^{\circ} \mathrm{C}$ and \\
$0.1-0.3 \mathrm{Mpa}$ \\
$\begin{array}{c}\text { Storage equip- } \\
\text { ment }\end{array}$ & - & $\begin{array}{c}\text { High compressed } \\
\text { bottle }\end{array}$ & $\begin{array}{c}\text { Low temperature } \\
\text { tank }\end{array}$ \\
$\begin{array}{ccc}\text { Price unit (Yin) } \\
\text { Note }\end{array}$ & $\begin{array}{c}\text { Low invest- } \\
\text { Yin } / \mathrm{m}^{3}\end{array}$ & $\begin{array}{c}\text { 3.0 - } 4.0 \mathrm{Yin} / \mathrm{m}^{3} \\
\text { ment }\end{array}$ & $\begin{array}{c}\text { Transportation }-5.0 \mathrm{Yin} / \mathrm{m}^{3} \\
\text { LNG gas station or } \\
\text { LNG tank }\end{array}$ \\
\hline
\end{tabular}


of three service methods. LNG has high price due to complicated processing and higher investment. So its sale prices are more than that of PNG and CNG. But LNG can be compressed into bottle and is good for personal requirement.

$1 \mathrm{~kg}$ acetylene and $1 \mathrm{~kg}$ natural gas' prices are 16 Chinese Yin and 12 Chinese Yin, respectively. Using natural gas as fuel instead of acetylene can save 4000 Yin per day and decrease oxygen consumption. It can reduce capital investments about 2 millions Chinese Yin per year.

\subsection{Natural Gas Used to Cut Metal}

Tang Hongqing [5] introduced how to synthesize ethylene with natural gas. Three methods, which include three steps, two steps and one step, were discussed in detail. Three steps method, two steps method and one step method mean natural gas-synthetic gas-methanol -ethylene, natural gas-methanol-ethylene and natural gas-eth-ylene, respectively.

$0.5 \mathrm{t}$ per year unit is established by Norsk Hydro Company with three steps method in 1995. This unit was continually operated at 90 days. The experimental results showed that unit was very stable and catalyst performance was well and high yield of ethylene and propylene were obtained.

Table 4 shows product yield of MTO (MethanolTo-Olefins) unit (500 t per year ethylene). $2370 \mathrm{kt}$ methanol coming from 20 billions natural gases was required to produce to $500 \mathrm{t}$ per year ethylene. At the same time 345 kt propylene and 100 kt butylenes were obtained.

Table 5 presents evaluation of naphtha and natural gas as feedstock to produce ethylene. The investment of using natural gas method is more than $43.6 \%$ that of using naphtha method, while the operating cost of using natural gas method is only $20 \%$ that of using naphtha method.

Natural gas is oxidized to methanol and then produced to ethylene with MTO method. This is two steps method. It is seldom used because it is very difficult to control the first step (oxidation reaction) and a lot of by-products are

Table 4. Product yield of MTO (Methanol-To-Olefins) unit (500 t/y ethylene).

\begin{tabular}{ccc}
\hline Name & Quantity, kt & Yield, \% \\
\hline Ethylene & 500 & 48.0 \\
Propylene & 345 & 33.0 \\
Butylenes & 100 & 9.6 \\
$\mathrm{C}_{5}^{+}$ & 25 & 2.4 \\
$\mathrm{H}_{2}, \mathrm{C}_{1}, \mathrm{C}_{2}, \mathrm{C}_{3}$ paraffin & 37 & 3.5 \\
$\mathrm{CO}_{2}$ & 5 & 0.5 \\
Coke & 30 & 3.0 \\
Water & 1328 & 0.0 \\
Total & 2370 & 100 \\
\hline
\end{tabular}

Table 5. Evaluation of naphtha and natural gas as feedstock to produce ethylene.

\begin{tabular}{lcc}
\hline & naphtha & natural gas \\
\hline Investment, billion Yin & 5.5 & 7.9 \\
Operating cost, billion Yin & 549 & 247 \\
By-product recycle & -447 & -379 \\
Net feedstock capital & 102 & -132 \\
Interest, \% & 25.9 & 29.9 \\
\hline
\end{tabular}

got. At the same time the separation processing is very complicated and has high requirement for reactor's material.

Natural gas is hydrogenated to produce ethylene. A lot of researcher studied on this method (OCM). And the good results were obtained. Table 6 shows the different catalysts having an effect on OCM method. Reaction temperature and conversion of ethylene are above $870^{\circ} \mathrm{C}$ and $36 \%$, respectively.

\subsection{Natural Gas Instead of Heavy Oil Fired to Produce Chromium Trioxide}

Song Ying [6] introduced that natural gas took the place of heavy oil as fuel to produce chromium trioxide. Disadvantages of heavy oil was used as fuel, such as, chromium trioxide processing is no continuing operation, heavy oil can't be fully burnt at the beginning and is discharged black flue and pollute environment; heavy oil's viscosity and freezing point are high. The heating systems are required due to storing and transporting and burning heavy oil; the quality of chromium trioxide has relationship with melting point; chromium trioxide is cracked with the increase of reaction temperature.

The composition of natural gas was shown in Table 7.

Advantages of heavy oil was used as fuel, such as, unit is very simple and easily operated; no more black flue is discharged and environment is protected; heat efficiency is improved in Table 8, heat efficiency increases $45 \%$

Table 6. An effect of the different catalysts on OCM method.

\begin{tabular}{cccc}
\hline Catalyst & $\begin{array}{c}\text { Temperature } \\
\left({ }^{\circ} \mathbf{C}\right)\end{array}$ & $\mathrm{CH}_{4} / \mathrm{O}_{2}$ & Conversion, \% \\
\hline Li-Mn-Ti & 1073 & 2.5 & 43.9 \\
Li-Mn & 1023 & 1.7 & 47.3 \\
Li-Na-Mn & 1073 & 3.0 & 38.3 \\
Na-W-Mn/SiO 2 & 1073 & 2.6 & 38.1 \\
Li-Na-Sn & 1073 & 2.0 & 41.2 \\
Li-Mn-Ti & 1073 & 2.5 & 37.3 \\
SnO 2 & 953 & 1.5 & 44.9 \\
Li-Mg & 998 & 1.7 & 47.3 \\
Li-Mg-Nd & 1003 & 2.0 & 57.1 \\
Li-Re & $873-1073$ & & 41.3 \\
Li-Mg-Mn & 973 & & 44.35 \\
Na-Mg-B & 1013 & & 36.4 \\
\hline
\end{tabular}


Table 7. Composition of natural gas, v\%.

\begin{tabular}{cc}
\hline Composition & Volume, v\% \\
\hline $\mathrm{CH}_{4}$ & 95.86 \\
$\mathrm{C}_{2} \mathrm{H}_{6}$ & 1.54 \\
$\mathrm{C}_{3} \mathrm{H}_{8}$ & 0.17 \\
$\mathrm{C}_{4} \mathrm{H}_{10}$ & 0.62 \\
$\mathrm{C}_{5} \mathrm{H}_{12}$ & 0.06 \\
$\mathrm{C}_{6} \mathrm{H}_{14}$ & 0.03 \\
$\mathrm{~N}_{2}$ & 1.13 \\
$\mathrm{CO}_{2}$ & 1.19 \\
\hline
\end{tabular}

Table 8. Comparing consumption of natural gas and heavy oil.

\begin{tabular}{ccc}
\hline Project & Natural gas & Heavy oil \\
\hline Consumption & $106.9 \mathrm{Nm}^{3}$ & $150 \mathrm{~kg}$ \\
Total input heat & $380.2 * 10^{4}$ & $627.4 * 10^{4}$ \\
energy, kJ & & \\
$\mathrm{O}_{2}$ consumption, & 212.410 & 334.138 \\
$\mathrm{Nm}^{3}$ & 110.748 & 242.4 \\
$\mathrm{CO}_{2}, \mathrm{Nm}^{3}$ & 214.516 & 205.2 \\
$\mathrm{H}_{2} \mathrm{O}, \mathrm{Nm}^{3}$ & 800.253 & 1294.8 \\
$\mathrm{~N}_{2}, \mathrm{Nm}^{3}$ & 0 & 0.158 \\
$\mathrm{SO}_{2}, \mathrm{Nm}^{3}$ & & \\
\hline
\end{tabular}

while amount of flue is decreased to $35.41 \%$; operating cost can be decreased, its equipment is very cheap and a lot of electricity and water and steam are saved.

Economic benefits are listed as follows:

1) Amount of chromium trioxide is $7000 \mathrm{t}$ per year, prices of heavy oil and natural gas are $1500 / \mathrm{t}$ and $1.6 / \mathrm{m}^{3}$, respectively, consumption of heavy oil and natural gas are $0.15 \mathrm{t} / \mathrm{tCrO}$ and $106.9 \mathrm{Nm}^{3} / \mathrm{tCrO}_{3}$, respectively, Costs of heavy oil per year $1500 * 0.15 * 7000=1.575$ millions dollars Costs of natural gas per year $106.9 * 1.6 *$ $7000=1.197$ millions dollars Saving cost $=1.575$ millions dollars -1.197 millions dollars $=0.378$ millions dollars.

2) The equipment of water circulation for heavy oil is easily fragile and about 20 parts needs to be replaced. The price of one part is 2000 Chinese Yin. Factory can save 40000 Chinese Yin per year.

The energy consumption of the natural gas system is reduced, such as, cooling water, steam and electricity.

\section{Conclusions}

In a word, using natural gas as high value production is promising option for energy reserve in China. Benefits of natural gas are listed as follow:

1) Displace the traditional energy (coal) and protect the local fragile environment, substitute for fossil fuel consumption transported from at least $1000 \mathrm{~km}$ and avoid pollutions emissions, such as $\mathrm{SO}_{2}$, NO, Total Suspended Particles and $\mathrm{CO}_{2}$.

2) Make good benefits for public and factory in the south and east of China cost-effectively.

3) Facilitate the local sustainable development and increase the local income and job opportunity.

\section{References}

[1] Z. Y. Ma, X. Y. Meng, H. W. Wang, W. Zhou and H. Y. Jiang, "Progress in Research of Oxalate Synthesis by Gas Phase Catalytic Coupling of CO,” Petrochemical, Vol. 38, No. 3, 2009, pp. 456-461.

[2] Z. L. Li, "Economic Introduction for Methanol to Generate Lower Carbon Olefin,” Chemical Catalysis and Methanol Technology, Vol. 6, No. 1, 2007, pp. 16-23.

[3] X. F. Zhang and D. Q. Zheng, "The Plasma Method for Acetylene Production from Natural Gas,” Natural Gas Industry, Vol. 23, No. 4, 1998, pp. 39-43.

[4] Y. W. Gong, F. H. Liu and Y. K. Lai, “Technology and Appliance of Natural Gas Cutting Metal,” Natural Gas Industry, Vol. 28, No. 8, 2003, pp. 117-119.

[5] H. Q. Tang, Z. W. Yuan and D. J. Jiang, "Study on and Develop Natural Gas Produced to Ethylene Processing," Chemical Engineering Design, Vol. 9, No. 1, 1999, pp. 58.

[6] Y. Song, W. Ji and X. Li, "Replacing Heavy Oil with Natural Gas to Produce Chromium Trioxide,” Shangdong Chemical Industry, Vol. 30, No. 4, 2001, pp. 37-38. 